\title{
2007-2016 Yılları Arasında Lider-Üye Etkileşim Teorisi Üzerine Yapılan Lisansüstü Tezlerin Meta-Analizi
}

\section{The Years Between 2007-2016 Meta-Analysis Of Graduate Thesis Study On Leader-Member Exchange Theory}

\author{
DOI $=\underline{10.17556 / \text { jef }_{.71455}}$
}

\author{
Şefika Şule ERÇETIN*, Mustafa ÖZKAN**
}

\section{Özet}

$\mathrm{Bu}$ çalışmada, Lider-Üye Etkileşimi Teorisi alanında tamamlanan lisansüstü tez çalışmalarının sentezlenerek değerlendirmesi, bilimsel analizi yapılarak yorumlanması ve yeni yapılacak çalışmalara yol göstermesi amaçlanmışıtır. Araştırma konusunu oluşturan lisansüstü tezler; Türkiye Yüksek Öğretim Kurumunun (YÖK) Ulusal Tez Merkezinde yapılan yüksek lisans ve doktora tezlerinin taranması sonucu elde edilmiştir. Bu çalışmada; 2016 yılına kadar Lider-Üye Etkileşimi Teorisi alanında tamamlandığı tespit edilen 31 (20 yüksek lisans ve 11 doktora) lisansüstü tez, meta-analiz yöntemi ile incelenmiștir. Türkiye'de Lider-Üye Etkileșimi Teorisi alanında, 2007 yılından itibaren tamamlanan lisansüstü tezlerin sayısının, günümüze doğru gelindiğinde arttığı ve son iki yılda (2014-2015) bu alanda yapılan çalışmalar toplam çalışmaların yarısını oluşturduğu görülmüsştür. Lider-Üye Etkileşimi Teorisi alanının gittikçe popülerleşmesi ve araştırılması, 21. yüzyılda kendilerini sürekli sorgulayan ve geliştirme yolları arayan örgütlerde ne kadar hayati bir öneme haiz olduğunu gösterdiği düşünülmektedir. Tezlerin araştırdığı konulara bakıldığında, neredeyse tamamına yakınında farklı konular üzerinde çalışıldığı, yarısından fazlasının "işletme" ve "eğitim" sektörlerine yönelik olduğu ve bunu "sağllk" sektörünün takip ettiği, tezlerin büyük bir bölümü Sosyal Bilimler Enstitüsü/İşletme Yönetimi Anabilim Dalında yapıldığı tespit edilmiştir.

Anahtar sözcük: Lider-üye etkileşimi, lisansüstü tez, meta naliz.

\section{Abstract}

In this study, it is aimed that postgraduate thesis' studies in the field of Leader-Member Exchange is evaluated being synthesized, interpreted being analyzed scientifically and instructed to the new studies. The thesis' studied are provided with searching postgraduate and doctoral thesis in the website of Thesis Center, Council of Higher Education. In this study, 31 postgraduate thesis' (20 of them are postgraduate thesis, 11 are doctoral thesis) on Leader-Member Exchange is studied by doing a meta-analyze. The number of studies in the field of Leader-Member Exchange has increased since 2007. It is understood that especially at the last two years (2014-2015), the studies on this field include half of the whole studies. The 
increasing studies on Leader- Member Exchange show that this field is really important for the organizations questioning themselves and trying to develop in the 21 st century. It is determined that most of the topics studied at the thesis' are different. Also, it is understood that more than half of the studies are for sectors of "business" and "education" and at the third "health". Most of the thesis" are written for Graduate School of Social Sciences and the Division of Business Administration.

Keywords: Leader-member exchange, postgraduate thesis, meta-analyze.

\section{Giriş}

Liderlik alanında yapılan çalışmalara baktığımızda, liderlik kavramı ve liderin tarzlarına yönelik olguların ve davranışların araştırıld1ğını görmekteyiz. Ancak 1970'li yıllara gelindiğinde sadece liderlerin tarzları değil, onları takip eden üyelerin,çalışanların algıları ve liderle olan paylaşımları ve etkileşimleri de dikkate alınarak, bunların da üzerinde durulmaya başlanmıştır.(Liden, R. C., \& Maslyn, J. M. 1998). Başlangıçta örgütlerde liderlerin,yöneticilerin çalışanlarına yönelik tutum ve davranışlarının genelde aynı olduğu ve üyelerle ortalama ilişkiler geliştirdikleri düşünülüyordu. Ancak daha sonraları yapılan araştırmalarda bu ilişkilerin örgüt içerisindeki grup ve bireylere göre farklılaştığı ortaya kondu(Scandura vd.,1984). Bunun sonucu olarak da literatürde "Leader-Member Exchange Theory" (LMX) olarak bilinen "Lider-Üye Etkileşim Teorisi" geliştirilmiştir(Dansereau vd., 1975). Bu teorinin dayandığ temel varsayım, liderlerin grup üyelerine aynı mesafede durmadıkları ve eşit paylaşımlarda bulunmadıklarıdır. Örgütlerde üyelerin farklı gruplar oluşturduğu ve bu gurupların liderle olan ilişkilerinin kalitesinin ve karşılıklı paylaşımların farklı olduğu belirlenmiştir(Yıldız, G. vd., 2008). Örgütlere yeni katılan bir üyenin çeşitli yaşantılardan ve rol evrelerinden geçerek lidere karşı örgütteki rolünü netleştirdiği görülmüştür. Buna göre, ya liderin yakın çevresinde daha samimi, informal ilişkiler içinde olacak ya da lidere daha uzak mesafede durup daha soğuk, formal ilişkiler geliştirecektir. Lider üye ilişkisinin niteliği üyelerin/astların/izleyicilerin örgüt içerisindeki rolünü oluşturur. Bu da üyelerin/astların/izleyicilerin rollerinin kurallara, politikalara, prosedürlere daha az karşıllklı güvene, daha seyrek ve biçimsel iletişime, astın amiri tarafından daha az destek görmesi ve ödüllendirmesine dayalı olan grup dışı üyelik rolü mü yoksa, yüksek 
güven, iletişim, destek ve resmi/özel ödüllerle desteklenen grup içi üyelik rolünde mi olacağını belirlediği görülmüştür.

İşte 21. yüzyılda örgütlerde üyelerinin verimliliğini, performanslarını, örgüte bağl1lığını, örgütsel vatandaşlık davranışını, örgütsel adalet algısını, örgütsel sessizliğin altında yatan nedenler gibi daha birçok konuyu sorgulayan ve geliştirmeye çalışan işletme ve yönetimlerde "Lider-Üye Etkileşim Teorisi" büyük önem arz etmektedir. Bu nedenle özellikle 2000 li yıllardan sonra liderlik üzerine yapılan çalışmalar bu alana kaymış ve daha da popülerleşmiştir. Bununla bağlantılı olarak üniversitelerde bu alanda yapılan lisansüstü tezlerin sayısında artış olduğu görülmüş ve "Lider-Üye Etkileşim Teorisi" alanında yapılan araştırmalar çoğalmıştır.

\section{Teorik Çerçeve}

Geleneksel liderlik yaklaşımları, liderin tüm çalışanlara benzer şekillerde davrandığını varsayımına dayanmaktadır.

Blanchard ve Hersey(1970) Lider üye etkileşimi oluşum sürecini "Liderlik Yaşam Döngüsü Teorisi” ile açıklamaktadır. Bu Döngü içerisinde lider-üye arasındaki ilişki; yabancılık aşaması,tanıdıklık aşaması,olgunlaşma aşaması olarak üç aşamada yaşandığını ileri sürmüştür.

“Ortalama Liderlik Yaklaşımı” ise liderin tüm çalışanlara benzer şekillerde davrandığını varsayımına dayanmaktadır. Ortalama liderlik davranışından sapmalar ise "hata" olarak değerlendirilip göz ardı edilmiştir.(Dansereau vd.,1975)

“Dikey İkili Bağlantı Modeli” (Vertical Dyad Linkage Model) olarak adlandırılan lider üye etkileşimi modeli, ilk kez Dansereau, Graen ve Haga tarafından 1975 yılında ileri sürülmüştür.Bu model, lider/yönetici ve üyeler/astlar arasındaki etkileşimi dikey ikili bir yaklaşım çerçevesinde ele almış ve literatürde "Leader-Member Exchange Theory" (LMX) olarak yeniden adlandırılmıştır.(Dansereau vd., 1975). 
"Leader-Member Exchange Theory" (LMX) olarak bilinen Lider Üye Etkileşimi (LÜE) modelinde, liderin tüm astlarına aynı şekilde davranmadığı, bunun yerine her bir astıyla farklı düzeyde ilişki ve paylaşımlar geliştirdiği varsayılmaktadır(Schriesheim vd., 1998). Bu ilişki ve paylaşımlar, iş akdinde yer alan şartlarla sınırlı olabileceği gibi(Graen vd., 1975), bu şartların ötesinde, karşılıklı saygı ve güvene dayalı güçlü bir etkileşimin sonucunda da gelişebilir.LÜE modeli, lider ve üyeler arasındaki ikili etkileşimleri ele alması açısından, geleneksel liderlik teorilerinden ayrılmakta, geleneksel liderlik modellerinde göz ardı edilen karşılıklı etkileşim süreci ve bu süreçteki farklılaşma Lider Üye Etkileşim Teorisinin araştırma konusunu oluşturmaktadir.

LÜE başlangıçta tek boyutlu bir kavram olarak ele alınmakla birlikte, çok boyutlu bir modelin lider ile üyeler arasındaki ilişkinin doğasını daha iyi açıklayabileceğini ortaya koymuştur.Graen ve Scandura, lider-üye arasındaki ilişkiyi, çeşitli rol yapma evrelerinin bir sonucu olarak görmüşler ve bu evreleri; rol üstlenme, rol oluşturma, rol rutinizasyonu olarak açıklamıştır. "Sosyal Mübadele Teorisine" (Blau, 1964) göre, ast ve üst arasındaki sosyal değişimlerin artışı lider-üye etkileşiminin niteliğini daha güçlü bir hale getirir. Örgütsel ortamdaki sosyal etkileşimlerde maddi ve maddi olmayan birçok şey değiş tokuş edilebilir. Örneğin; tavsiye, enformasyon, çaba, sosyal destek ve arkadaşlık sosyal geçerlilik olarak tanımlanabilir(Yıldız, G. vd., 2008).

Liden ve Maslyn (1998), lider ile astları arasındaki ilişkileri, “etki", "vefakârlık", "katkı" ve "profesyonel saygı" boyutları ile ölçen bir ölçek geliştirmişlerdir. Etki, ikili içinde yer alan üyelerin birbirlerine karşı besledikleri duygular, iş bağlantılı veya profesyonel değerlerden ziyade kişiler arası etkileşime, ilgiye dayanmaktadır. Vefakârlık, "lider ve üyelerin birbirlerine karşı vefalı olma derecesi" olarak tanımlanabilir. Katkı "ilişkinin taraflarının ortak amaçlar için ortaya koydukları iş ile ilgili faaliyetlerin algılanan miktar ve kalitesi” şeklinde tanımlamıştır. Profesyonel saygı boyutu, "ilişkinin taraflarından her birinin organizasyon içinde ya da dişında sahip olduğu saygınlık derecesine yönelik algı” olarak tanımlanmıştır.(Yıldız, G. vd., 2008). 


\section{Yöntem}

\section{Araştırmanın Modeli}

Lider-Üye Etkileşimi alanında yapılan lisansüstü tezlerin değerlendirilmesinin amaçlandığı bu çalışmada meta-analiz yöntemi kullanılmıştır. Meta-analiz çalışması,araştırmalarda belirli bir konuda ortaya konulan analizlerin bir araya getirilerek sentezlenmesi ve değerlendirilmesini amaçlar(Büyüköztürk vd., 2009).

\section{Verilerin Toplanmast}

Araştırma konusunu oluşturan lisansüstü tezler; Türkiye Yüksek Öğretim Kurumu Ulusal Tez Merkezinde yapılan yüksek lisans ve doktora tezlerinin "tez adı" kategorisinde, anahtar kelime alanına "lider üye etkileşimi” sözcükleri girilerek taranması sonucu elde edilmiştir.

\section{Kapsam ve Sintrlılık}

Bu çalışma Türkiye Yüksek Öğretim Kurumunun (YÖK) Ulusal Tez Merkezinde yapılan tarama sonucu, 2016 yılına kadar lider üye etkileşimi alanında tamamlandığı tespit edilen 31 lisansüstü tezle sinirlidir.

\section{Verilerin Analizi}

Yapılan tarama sonucunda Lider-Üye Etkileșimi Teorisi Alanında tamamlanmış toplam 31 lisansüstü tez tespit edilmiştir. Veriler SPSS 20 istatistiksel veri analizi paket programı ile analiz edilmiştir. Kontrol değişkenlerine ilişkin veriler, frekans ve yüzde değerleri kullanılarak değerlendirilmiştir. SPSS 20 istatistiksel veri analizi paket programı ortamında tezlerin türleri (yüksek lisans ve doktora), hazırlandığ1 yıllar, hazırlandığı sektörlere (işletme, eğitim, sağlık vb.), hangi üniversitelerde, enstitülerde ve anabilim dalında hazırlandıklarına, ve araştırma konularına (İş tatmini, Motivasyonel dil, Örgütsel adalet, Örgütsel vatandaşlık davranışı vb.) göre kodlamaları yapılarak analiz edilmiştir. 


\section{Bulgular}

Çalışmanın bu bölümünde Lider-Üye Etkileşimi Teorisi Alanında Yapılan Lisansüstü Tezlerin; Yıllara, Yapıldığı Sektörlere, Üniversitelere, Enstitülere, Anabilim Dallarına, Tezlere Ait Konulara ve Tezlerin Türlerine Göre Dağılımı tablolar halinde sunulmuştur.

Tablo 1. Lider-Üye Etkileşimi Alanında Yapılan Lisansüstü Tezlerin Yıllara Göre Dağılımı

\begin{tabular}{|c|c|c|c|c|c|c|c|}
\hline \multicolumn{8}{|c|}{ Türü } \\
\hline & & \multicolumn{2}{|c|}{ Yüksek Lisans } & \multicolumn{2}{|c|}{ Doktora } & \multicolumn{2}{|c|}{ Toplam } \\
\hline & & $\mathbf{f}$ & $\%$ & $\mathbf{f}$ & $\%$ & $\mathbf{f}$ & $\%$ \\
\hline \multirow{10}{*}{ Yıl } & 2007 & 0 & $0,0 \%$ & 1 & $9,1 \%$ & 1 & $3,2 \%$ \\
\hline & 2008 & 2 & $10,0 \%$ & 1 & $9,1 \%$ & 3 & $9,7 \%$ \\
\hline & 2009 & 1 & $5,0 \%$ & 1 & $9,1 \%$ & 2 & $6,5 \%$ \\
\hline & 2010 & 1 & $5,0 \%$ & 2 & $18,2 \%$ & 3 & $9,7 \%$ \\
\hline & 2011 & 2 & $10,0 \%$ & 0 & $0,0 \%$ & 2 & $6,5 \%$ \\
\hline & 2012 & 3 & $15,0 \%$ & 1 & $9,1 \%$ & 4 & $12,9 \%$ \\
\hline & 2013 & 3 & $15,0 \%$ & 0 & $0,0 \%$ & 3 & $9,7 \%$ \\
\hline & 2014 & 4 & $20,0 \%$ & 3 & $27,3 \%$ & 7 & $22,6 \%$ \\
\hline & 2015 & 4 & $20,0 \%$ & 2 & $18,2 \%$ & 6 & $19,4 \%$ \\
\hline & TOPLAM & 20 & $100,0 \%$ & 11 & $100,0 \%$ & 31 & $100,0 \%$ \\
\hline
\end{tabular}

Tablo 1 incelendiğinde, Türkiye'de Lider-Üye Etkileşimi Teorisi alanında tamamlanan lisansüstü tezlerin sayısının, 2007 yılında \% 3,2 olduğu, 2007 yılından itibaren günümüze doğru gelindiğinde arttığ 1 ve son iki yılda(2014-2015) bu alanda yapılan araştırmaların, toplam 
çalışmaların \%42 sini oluşturduğu görülmüştür. Tablo 1'de dikkat çeken önemli bir nokta doktora tez sayılarının yüksek lisans sayılarının yaklaşık yarısı olduğunun gözlemlenmesidir.

Tablo 2. Lider-Üye Etkileşimi Alanında Yapılan Lisansüstü Tezlerin Sektörlere Göre Dağılımı

\begin{tabular}{|c|c|c|c|}
\hline & & $\mathbf{f}$ & $\%$ \\
\hline \multirow{13}{*}{ Sektör } & İşletme & 9 & $29,0 \%$ \\
\hline & Turizm ve otelcilik & 1 & $3,2 \%$ \\
\hline & Belediyecilik & 1 & $3,2 \%$ \\
\hline & Kargo & 1 & $3,2 \%$ \\
\hline & İletişim & 1 & $3,2 \%$ \\
\hline & Eğitim & 9 & $29,0 \%$ \\
\hline & Endüstri & 1 & $3,2 \%$ \\
\hline & Sağlık & 4 & $12,9 \%$ \\
\hline & Sivil savunma & 1 & $3,2 \%$ \\
\hline & Yazilım & 1 & $3,2 \%$ \\
\hline & Bankacılık & 1 & $3,2 \%$ \\
\hline & Gida & 1 & $3,2 \%$ \\
\hline & TOPLAM & 31 & $100,0 \%$ \\
\hline
\end{tabular}

Tablo 2'de görüldüğü gibi; hazırlanan lisansüstü tezlerin \% 29'u $(\mathrm{f}=9)$ işletme sektörüne, \% 29'u ( $\mathrm{f}=9$ ) ise eğitim sektörüne yöneliktir. Bunu \% 12,9 ( $\mathrm{f}=4)$ oranında sağlık sektörü yönelik tezler izlemektedir. $\% 3,2(\mathrm{f}=1)$ oranında turizm ve otelcilik sektörü, \% 3,2 (f=1) oranında belediyecilik sektörü, \% 3,2 ( $\mathrm{f}=1)$ oranında kargo sektörü, $\% 3,2(\mathrm{f}=1)$ oranında iletişim sektörü, $\% 3,2(\mathrm{f}=1)$ oranında endüstri sektörü, \% 3,2 ( $\mathrm{f}=1)$ oranında sivil savunma sektörü,\% 3,2 (f=1) 
oranında yazılım sektörü, \% 3,2 (f=1) oranında bankacılık sektörü, \% $3,2(\mathrm{f}=1)$ oranında gıda sektörüne yöneliktir.

Tablo 3. Lider-Üye Etkileşimi Alanında Yapılan Lisansüstü Tezlerin Üniversitelere Göre Dağılımı

\begin{tabular}{|c|c|c|c|c|c|c|}
\hline & \multicolumn{6}{|c|}{ Türü } \\
\hline & \multicolumn{2}{|c|}{$\begin{array}{l}\text { Yüksek- } \\
\text { Lisans }\end{array}$} & \multicolumn{2}{|c|}{ Doktora } & \multicolumn{2}{|c|}{ Toplam } \\
\hline & f & $\%$ & f & $\%$ & f & $\%$ \\
\hline $\begin{array}{l}\text { Yeditepe } \\
\text { Üniversitesi }\end{array}$ & 2 & $10,0 \%$ & 1 & $9,1 \%$ & 3 & $9,7 \%$ \\
\hline $\begin{array}{l}\text { Hacettepe } \\
\text { Üniversitesi }\end{array}$ & 0 & $0,0 \%$ & 2 & $18,2 \%$ & 2 & $6,5 \%$ \\
\hline $\begin{array}{l}\text { Eskişehir } \\
\text { Osmangazi } \\
\text { Üniversitesi }\end{array}$ & 1 & $5,0 \%$ & 0 & $0,0 \%$ & 1 & $3,2 \%$ \\
\hline $\begin{array}{l}\text { Süleyman } \\
\text { Demirel Ün- } \\
\text { iversitesi }\end{array}$ & 0 & $0,0 \%$ & 1 & $9,1 \%$ & 1 & $3,2 \%$ \\
\hline $\begin{array}{l}\text { Zirve Ün- } \\
\text { iversitesi }\end{array}$ & 1 & $5,0 \%$ & 0 & $0,0 \%$ & 1 & $3,2 \%$ \\
\hline Gebze & 2 & $10,0 \%$ & 0 & $0,0 \%$ & 2 & $6,5 \%$ \\
\hline Yüksek & & & & & & \\
\hline $\begin{array}{l}\text { Teknoloji } \\
\text { Enstitüsü } \\
\end{array}$ & & & & & & \\
\hline Harp Akad- & 1 & $5,0 \%$ & 0 & $0,0 \%$ & 1 & $3,2 \%$ \\
\hline
\end{tabular}




\begin{tabular}{|c|c|c|c|c|c|c|c|}
\hline \multirow[t]{19}{*}{ Üniversite } & \multicolumn{7}{|l|}{$\begin{array}{l}\text { emileri } \\
\text { Komutanlığı } \\
\end{array}$} \\
\hline & Balıkesir & 1 & $5,0 \%$ & 1 & $9,1 \%$ & 2 & $6,5 \%$ \\
\hline & \multicolumn{7}{|l|}{ Üniversitesi } \\
\hline & $\begin{array}{l}\text { Erciyes Ün- } \\
\text { iversitesi }\end{array}$ & 1 & $5,0 \%$ & 0 & $0,0 \%$ & 1 & $3,2 \%$ \\
\hline & Afyon & 0 & $0,0 \%$ & 1 & $9,1 \%$ & 1 & $3,2 \%$ \\
\hline & \multirow{2}{*}{\multicolumn{7}{|c|}{$\begin{array}{l}\text { Kocatepe } \\
\text { Üniversitesi }\end{array}$}} \\
\hline & & & & & & & \\
\hline & Çankaya & 1 & $5,0 \%$ & 0 & $0,0 \%$ & 1 & $3,2 \%$ \\
\hline & \multicolumn{7}{|l|}{ Üniversitesi } \\
\hline & Marmara & 3 & $15,0 \%$ & 2 & $18,2 \%$ & 5 & $16,1 \%$ \\
\hline & \multicolumn{7}{|l|}{ Üniversitesi } \\
\hline & $\begin{array}{l}\text { Haliç Ün- } \\
\text { iversitesi }\end{array}$ & 1 & $5,0 \%$ & 1 & $9,1 \%$ & 2 & $6,5 \%$ \\
\hline & $\begin{array}{l}\text { Kocaeli Ün- } \\
\text { iversitesi }\end{array}$ & \multicolumn{3}{|c|}{ iversitesi } & $0,0 \%$ & & $3,2 \%$ \\
\hline & $\begin{array}{l}\text { Gediz Ün- } \\
\text { iversitesi }\end{array}$ & \multicolumn{2}{|c|}{ iversitesi } & & $0,0 \%$ & 1 & $3,2 \%$ \\
\hline & $\begin{array}{l}\text { Okan Ün- } \\
\text { iversitesi } \\
\end{array}$ & 1 & $5,0 \%$ & 0 & $0,0 \%$ & 1 & $3,2 \%$ \\
\hline & Kara Harp & 2 & $10,0 \%$ & 1 & $9,1 \%$ & 3 & $9,7 \%$ \\
\hline & \multirow{2}{*}{\multicolumn{7}{|c|}{$\begin{array}{l}\text { Okulu } \\
\text { Komutanlığı } \\
\end{array}$}} \\
\hline & & & & & & & \\
\hline & İstanbul & 1 & $5,0 \%$ & 1 & $9,1 \%$ & 2 & $6,5 \%$ \\
\hline
\end{tabular}




\begin{tabular}{lllllll} 
Üniversitesi & & & & & & \\
\hline TOPLAM & 2 & 100,0 & 1 & 100,0 & 3 & 100,0 \\
& 0 & $\%$ & 1 & $\%$ & 1 & $\%$ \\
\hline
\end{tabular}

Bu çalışmada, Türkiye'de 18 farklı üniversitede Lider-Üye Etkileşimi alanında tez hazırlandığı tespit edilmiştir. Tablo 3'te görüldüğü gibi, Lider-Üye Etkileşimi alanında en fazla lisansüstü tez, Marmara Üniversitesi ( $\mathrm{f}=5, \%$ 16,1) bunu Yeditepe Üniversitesi ve Kara Harp Okulu Komutanlığ $(\mathrm{f}=3, \%$ 9,7) takip etmektedir. Hacettepe Üniversitesi, Gebze Yüksek Teknoloji Enstitüsü, Balıkesir Üniversitesi, Haliç Üniversitesi ve İstanbul Üniversitesinde $(\mathrm{f}=2, \%$ 6,5) ikişer lisansüstü tez hazırlanmıştır. Diğer üniversitelerde ise $(\mathrm{f}=1, \% 3,2)$ birer lisansüstü tez hazırlanmıştır.

Tablo 4. Lider-Üye Etkileşimi Alanında Yapılan Lisansüstü Tezlerin Enstitülere Göre Dağılımı

\begin{tabular}{llll}
\hline & & f & \% \\
\hline \multirow{4}{*}{ Enstitü } & Sosyal Bilimler Enstitüsü & 25 & $80,6 \%$ \\
\cline { 2 - 4 } & Fen bilimleri Enstitüsü & 1 & $3,2 \%$ \\
\cline { 2 - 4 } & Savunma Bilimleri Enstitüsü & 3 & $9,7 \%$ \\
\cline { 2 - 4 } & Sağlı Bilimleri Enstitüsü & 1 & $3,2 \%$ \\
\cline { 2 - 4 } & Stratejik Araştırmalar Enstitüsü & 1 & $3,2 \%$ \\
\cline { 2 - 4 } & TOPLAM & $\mathbf{3 1}$ & $\mathbf{1 0 0 , 0} \%$ \\
\hline & & & \\
\hline
\end{tabular}

Çalışmada 18 farklı üniversitenin toplamında, 5 farklı enstitüde Lider-Üye Etkileşimi alanında tez hazırlandığı tespit edilmiştir. Tablo 4'te görüldüğü gibi, Lider-Üye Etkileşimi alanında en fazla lisansüstü tez, sosyal bilimler enstitüsü $(\mathrm{f}=25, \%$ 80,6) olması dikkat 
çekmektedir. bunu savunma bilimleri enstitüsü $(\mathrm{f}=3, \% 9,7)$ takip etmektedir. Diğer enstitülerde ise $(\mathrm{f}=1, \% 3,2)$ birer lisansüstü tez hazırlanmıştır.

Tablo 5. Lider-Üye Etkileşimi Alanında Yapılan Lisansüstü Tezlerin Anabilim Dallarına Göre Dağılımı

\begin{tabular}{|c|c|c|c|}
\hline & & f & $\%$ \\
\hline \multirow{13}{*}{ Anabilim Dalı } & İşletme Yönetimi Anabilim Dalı & 11 & $35,5 \%$ \\
\hline & İnsan Kaynakları Yönetimi Bilim Dalı & 1 & $3,2 \%$ \\
\hline & Savunma Kaynakları Yönetimi Anabilim Dalı & 1 & $3,2 \%$ \\
\hline & Turizm İşletmeciliği ve Otelcilik Anabilim Dalı & 1 & $3,2 \%$ \\
\hline & Örgütsel Davranış Bilim Dalı & 4 & $12,9 \%$ \\
\hline & Yönetim ve Organizasyon Bilim Dalı & 5 & $16,1 \%$ \\
\hline & Endüstri Mühendisliği Anabilim Dalı & 1 & $3,2 \%$ \\
\hline & Savunma Yönetimi Anabilim Dalı & 3 & $9,7 \%$ \\
\hline & Hemşirelik Anabilim Dalı & 1 & $3,2 \%$ \\
\hline & Sınıf Öğretmenliği Anabilim Dalı & 1 & $3,2 \%$ \\
\hline & Eğitim Yönetimi ve Denetimi Anabilim Dalı & 1 & $3,2 \%$ \\
\hline & İșletme Yönetimi ve Organizasyon Bilim Dalı & 1 & $3,2 \%$ \\
\hline & TOPLAM & 31 & $100,0 \%$ \\
\hline
\end{tabular}

Çalışmada 12 farklı Anabilim/bilim Dalında Lider-Üye Etkileşimi alanında tez hazırlandığı tespit edilmiştir. Tablo 5 'te görüldüğü gibi, Lider-Üye Etkileşimi alanında en fazla lisansüstü tez, işletme yönetimi anabilim dalında ( $\mathrm{f}=11, \%$ 35,5), olması dikkat çekmektedir. Bunu sırasıyla; yönetim ve organizasyon bilim dalı $(f=5, \% 16,1)$, örgütsel davranış bilim dalı ( $\mathrm{f}=4, \% 12,9)$, savunma yönetimi ana- 
bilim dalı ( $\mathrm{f}=3, \% 9,7)$, takip etmektedir. Diğer anabilim/bilim dallarında ise ( $\mathrm{f}=1, \% 3,2)$ birer lisansüstü tez hazırlanmıştır.

Tablo 6. Lider-Üye Etkileşimi Alanında Yapılan Lisansüstü Tezlerin Konulara Göre Dağılımı

\begin{tabular}{llll}
\hline & f & $\%$ \\
\hline Bilgi sistemleri uygulamaları & 1 & $3,2 \%$ \\
\cline { 2 - 4 } Bireysel ve örgütsel sonuçlar & 1 & $3,2 \%$ \\
\cline { 2 - 4 } Bireysel yetkinlik & 1 & $3,2 \%$ \\
\cline { 2 - 4 } Çalışan tutumları & 1 & $3,2 \%$ \\
\hline Çatışma yönetim tarzları & 1 & $3,2 \%$ \\
\hline Duygusal zeka faktörleri & 1 & $3,2 \%$ \\
\hline Gruplaşmalar, güç, etkileşimler ve motivasyon & 1 & $3,2 \%$ \\
\hline Hizmetkar liderlik & 1 & $3,2 \%$ \\
\hline İş doyumu & 1 & $3,2 \%$ \\
\hline İş güvenliği & 1 & $3,2 \%$ \\
\hline İşs stresi & 1 & $3,2 \%$ \\
\hline İş tatmini & 2 & $6,5 \%$ \\
\hline İșe adanma & 1 & $3,2 \%$ \\
\hline İzlenim yönetimi taktikleri & 1 & $3,2 \%$ \\
\hline Kişilik & 1 & $3,2 \%$ \\
\hline Motivasyonel dil & 2 & $6,5 \%$ \\
\hline Müsamahacı ve kısıtlayıcı örgüt kültürü & 1 & $3,2 \%$ \\
\hline Örgütsel adalet & 2 & $6,5 \%$ \\
\hline Örgütsel adalet algısı ve tükenmişlik & $3,2 \%$ \\
\hline
\end{tabular}




\begin{tabular}{lcc}
\hline Örgütsel bağlılık ile işten ayrılma niyeti & 1 & $3,2 \%$ \\
\hline Örgütsel sessizlik & 1 & $3,2 \%$ \\
\hline Örgütsel vatandaşlık davranıșı & 2 & $6,5 \%$ \\
\hline $\begin{array}{l}\text { Psikolojik sözleşme ihlali ile örgüte karşı sinik } \\
\text { tutum }\end{array}$ & 1 & $3,2 \%$ \\
\hline Takım etkinliği & 1 & $3,2 \%$ \\
\hline Tükenmişlik ilişkisi & 1 & $3,2 \%$ \\
\hline Yabancılaşma & 1 & $3,2 \%$ \\
\hline Yöneticiye güven ve iş tatmini & 1 & $3,2 \%$ \\
\hline TOPLAM & $\mathbf{3 1}$ & $\mathbf{1 0 0 , 0} \%$ \\
\hline
\end{tabular}

Tablo 6' da görüldüğü gibi, Lider-Üye Etkileşim teorisi ile birlikte araştırılan konulardan; iş tatmini, motivasyonel dil, örgütsel adalet ve örgütsel vatandaşlık davranışı $(\mathrm{f}=2, \% 6,4)$ alanlarında ikişer lisansüstü tez, diğer konularda ise $(\mathrm{f}=1, \% 3,2)$ birer lisansüstü tez hazırlanmıştır. Tezlerin araştırdığı konulara bakıldığında, neredeyse tamamına yakınında farklı konular üzerinde çalışıldığı tespit edilmiştir.

\section{Sonuç ve Tartışma}

Bu çalışmada 2007-2016 yılları arasında, Lider-Üye Etkileşimi Teorisi alanında tamamlanan lisansüstü tezlerin incelenmesi sonucunda elde edilen bulgular doğrultusunda; Lider-Üye Etkileşimi Teorisi alanındaki gelişmelerin tespit edilmesinin ve Lider-Üye Etkileşimi Teorisi ile bağlantılı konular belirlenerek, Lider-Üye Etkileşimi Teorisinin önemini arttıran konular saptanmaya çalışılmıştır. Türkiye Yüksek Öğretim Kurumunun (YÖK) Ulusal Tez Merkezinde yapılan yüksek lisans ve doktora tezlerinin taranması sonucunda 2016 y1lına kadar Lider-Üye Etkileşimi Teorisi alanında tamamlandığı tespit edilen 31 (20 yüksek lisans ve 11 doktora) lisansüstü tez, meta-analiz yöntemi ile incelendiğinde, Türkiye'de Lider-Üye Etkileşimi Teorisi alanında, 
2007 yılından itibaren tamamlanan lisansüstü tezlerin sayısının, günümüze doğru gelindiğinde arttığı ve son iki yılda(2014-2015) bu alanda yapılan çalışmalar toplam çalışmaların yarısını oluşturduğu görülmüş̧ür. Lider-Üye Etkileşimi Teorisi alanının gittikçe popülerleşmesi ve araştırılması bizlere, 21. yüzyılda kendilerini sürekli sorgulayan ve geliştirme yolları arayan örgütlerde, Lider-Üye Etkileşimi Teorisinin ne kadar önemli olduğunu göstermektedir. Liderlik, günümüz örgütlerinde çok önemli bir kavram haline gelmiş ve adeta açılması çok zor kapıların anahtarı konumuna gelmiştir. Tabi ki liderlik kavramı liderin etrafındaki astları, üyeleri, izleyicileri ve ya örgütteki çalışanları ile bir anlam ifade etmektedir. Lider astlarının varlığında var olan kişidir. Bu yüzden örgütler üzerinde yapılan saha çalışmaları bu alana kaymış ve liderler, yöneticiler astları ile olan münasebetlerini ve ilişkilerini sorgulayarak geliştirme çabası içine girmişlerdir. Özellikle 2000 yılından önce ciddi çalışmaların yapılmadığı Lider-Üye Etkileşimi Teorisi alanının, 2000 yılından sonra yapılan araştırmaların artan bir ivmeyle günümüze kadar geldiği görülmüştür.

Hazırlanan doktora tezlerin sayılarının yüksek lisans tez sayılarının altında kalması, üniversitelerde bu alanda uzmanlaşmış akademik personel sayısının az olması ve doktora programlarına ait kadroların sayısının yeterli olmamasıyla açıklanabilir. 2014-2015 yıllarında tamamlanan yüksek lisans tezlerinin sayısı incelendiğinde 2016-2020 döneminde ise doktora tez çalışmalarında bir artışın olabileceği değerlendirilmektedir. 2014 sonrasında tamamlanan yüksek lisans ve doktora tez sayılarındaki artış, bu alanda lisansüstü tezi tamamlayan araştırmacıların alandaki yayın sayısının ve kalitesinin artmasına katkı sağlayacağı düşünülmektedir. Ayrıca yurt içinde Lider-Üye Etkileşimi Teorisi alanında panel ve sempozyumların organize edilmesi gerektiği söylenebilir. Bu tür çalışmalar sayesinde araştırmacıların bir araya gelerek görüşlerini ve bildirilerini paylaşılmasının önemli olduğu düşünülmektedir.

Lider-Üye Etkileşimi Teorisi alanında yapılan araştırmalara bakıldığında, en fazla işletme ve eğitim sektöründe çalışma yapıldığı göze çarpmaktadır. $\mathrm{Bu}$ sektörleri sağlık sektörünün izlediği görülmektedir. $\mathrm{Bu}$ aslında yönetim ve organizasyon temelli sektör- 
lerde yönetici, lider, ast, çalışan kavramların ne kadar önemli olduğunun ve araştırılması gerektiğinin doğal bir sonucudur. Artık günümüzde bu sektörlerdeki örgütlerde üyelerin,çalışanların iş performansını yükseltmenin onları anlamadan ve onlarla kaliteli ilişsiler kurmaktan geçmekte olduğu bilinmektedir. Sadece bu üç sektörde değil, bu çalışmada adı geçen diğer sektörlerde ve daha bir çok sektörde Lider-Üye Etkileşiminin araştırılması gerektiği düşünülmektedir.

Lider-Üye Etkileşim teorisi ile birlikte araştırılan konulara baktığımızda, örgütler için önemli olan birçok kavramın araştırıldığını görmekteyiz. Yapılan araştırmaların birkaç konu hariç tamamına yakınında farklı konuların araştırıldığı saptanmıştır. Bu da bize yapılan araştırmalardaki özgünlüğü göstermektedir. Alandaki araştırmalar neticesinde, örgütlerde yönetici/müdür/amir pozisyonundaki kişilerin maiyetleri ile kurmuş oldukları bu etkileşimlerin ve ilişkilerin niteliğinin; örgüt üyelerinin, çalışanların performanslarını, örgüte bağlılığını, örgütsel vatandaşlık davranışını, örgütsel adalet algısını, örgütsel sessizliği, işteki tatminini ve doyumunu, işten ayrılma niyetini ve bütün bunların sonucunda personel devir oranı gibi bazı konulara etkisi araştırılmıştır. Lider-Üye Etkileşimi Teorisi alanında yapılan çalışmalara baktığımızda, bu konuların hemen hemen hepsinde araştırmalar yapılmış ve araştırılan bütün bu konular üzerinde, Lider-Üye Etkileşim düzeyinin anlamlı ve doğrudan bir etkisinin olduğu anlaşılmıştır.

Lider-Üye Etkileşimi Teorisi alanında tamamlanan lisansüstü tezler incelendiğinde, üniversitelerin farklı enstitülerinde ve farklı anabilim dallarında yapıldığı anlaşılmaktadır. Çalışmaların \% 80 i sosyal bilimler enstitülerinde yapıldığı görülmektedir. sosyal bilimler enstitülerinde ise başlıca; işletme yönetimi anabilim dalı, yönetim ve organizasyon bilim dalı ve örgütsel davranış bilim dalı alanlarında tez hazırlanmıştır. Savunma bilimleri enstitüsünde savunma yönetimi anabilim dalında araştırmalar yapılmıştır. Yapılan çalışmalara bakıldığında eğitim yönetimi ve denetimi anabilim dalında sadece bir tezin hazırlandığ yapılmıştır ancak bu çalışmaların yanlıca biri eğitim yönetimi ve denetimi anabilim dalında yapılmıştır. Bu analizlere göre anabilim dal- 
larında, Lider-Üye Etkileşimi Teorisine yönelik; işletmelerdeki örgütlerde,okullar ve üniversiteler gibi eğitim kurumlarındaki örgütlerde, savunma ve güvenlik örgütlerinde tez araştırmaları yapılmıştır. Üniversitelerde eğitim yönetimi, teftişi, planlaması ve ekonomisi alanında açılan akademisyen kadrolarının ve doktora tez programı kontenjanlarının arttırılması Lider-Üye Etkileşimi Teorisinin gelişme sürecine katkı sağlayabileceği düşünülmektedir.

Yayımlanmış yüksek lisans ve doktora tezlerinin verileri 1şığında hali hazırdaki uygulamaların güncellenmesi ve yapılan çalışmaların etkiliğinin ortaya konulması açısından aynı konudaki çalışmaların süreklilik arz etmesi, bilimsel gelişmelerin öncülügünde Lider-Üye Etkileşim kalitesinin gelişmesine fayda sağlayacağı değerlendirilmektedir.

\section{Kaynaklar}

Blau, P. M. (1964). Exchange and power in social life. Transaction Publishers.

Büyüköztürk, Ş., Çakmak, E. K., Akgün, Ö. E., Karadeniz, Ş. \& Demirel, F. (2009). Bilimsel araştırma yöntemleri, Pege Akademi Yayınları, Ankara.

Dansereau, Fred-Graen, George-J. Haga \& William (1975), “A Vertical Dyad Linkage Approach to Leadership within Formal Organizations", Organizational Behavior and Human Performance, Vol: 13, ss. 46-78

Hersey, P., Blanchard, K. H. \& Natemeyer, W. E. (1979). Situational leadership, perception, and the impact of power. Group \& Organization Studies, (pre1986), Dec 1979, 4, pg. 418.

Liden, R. C., \& Maslyn, J. M. (1998). Multidimensionality of leader-member exchange: An empirical assessment through scale development. Journal of Management, 24(1), 43-72. doi: 10.1177/014920639802400105

Scandura, Terri A. \& Graen, George (1984), "Moderating Effects of Initial LeaderMember Exchange Status on the Effects of a Leadership Intervention", Journal of Applied Psychology, Vol: 69, ss. 428-436.

Schriesheim, Chester A., Linda L. Neider ve Terri A. Scandura(1998). Delegation and Leader-Member Exchange: Main Effects,Moderators, and Measurement Issues, The Academy of Management Journal, Vol.41, No.3, 298-318.

Yıldız, G., Özutku, H. \& Çevrioğlu, E. (2008). Lider-Üye Etkileşimine Çok Boyutlu Yaklaşım: Liden ve Maslyn'in Dört Boyutlu Lider-Üye Etkileşim Ölçeğinin 
Psikometrik Özelliklerine Yönelik Görgül Bir Araştırma, Akademik Incelemeler, 3(1), 95-123.

Yüksek Öğretim Kurumu (2016). UlusalTezMerkezi. 19.3.2016 tarihinde https://tez.yok.gov.tr/UlusalTezMerkezi adresi veri tabanından yararlanılmıştır. 